\title{
TEORI KONSUMSI
}

Makalah ini disusun untuk memenuhi tugas kelompok pada mata kuliah

Ekonomi Mikro Syariah

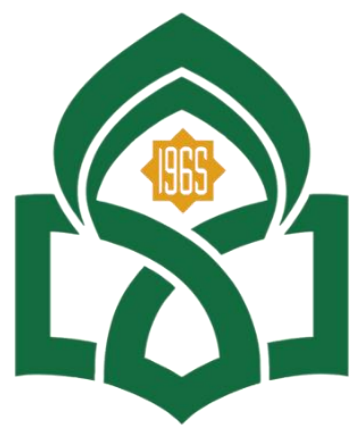

UNIVERSITAS ISLAM NEGERI

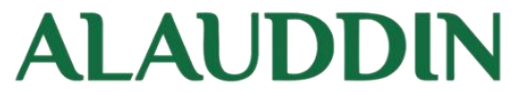

M A K A S S A R

KELOMPOK 5 :

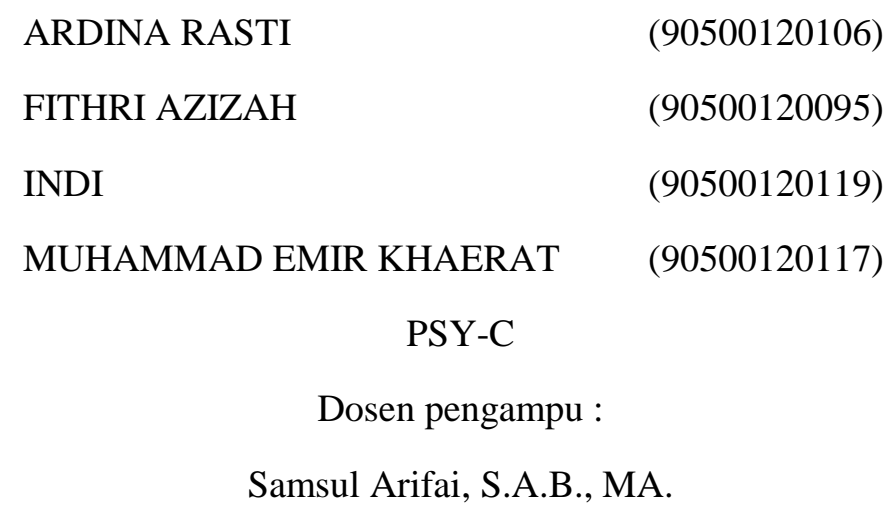




\section{KATA PENGANTAR}

Puji syukur kami panjatkan ke hadirat Tuhan Yang Maha Esa. Atas rahmat dan hidayahNya, penulis bisa menyelesaikan makalah yang berjudul "Teori Konsumsi"

Tidak lupa penulis mengucapkan terima kasih kepada Bapak Samsul Arifai selaku dosen pengampu Mata Kuliah Ekonomi Mikro Syariah yang telah membantu penulis dalam mengerjakan makalah ini. Penulis juga mengucapkan terima kasih kepada teman-teman yang telah berkontribusi dalam pembuatan makalah ini.

Penulis menyadari ada kekurangan pada makalah ini. Oleh sebab itu, saran dan kritik senantiasa diharapkan demi perbaikan karya penulis. Penulis juga berharap semoga makalah ini mampu memberikan pengetahuan tentang teori konsums itu sendiri.

Makassar, 19 Oktober 2021

Penulis 


\section{DAFTAR ISI}

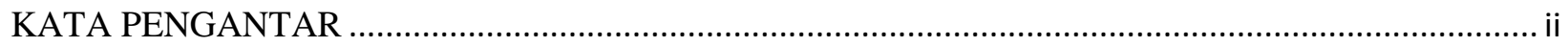

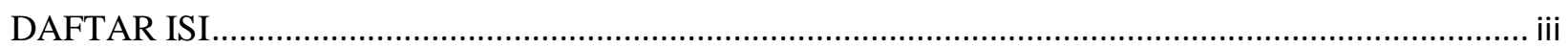

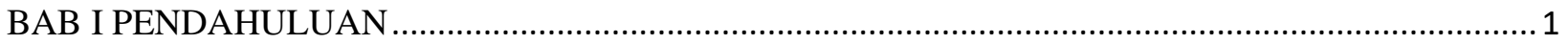

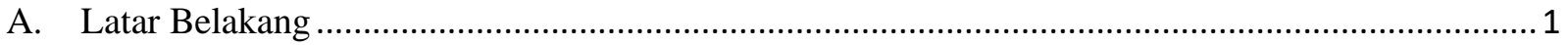

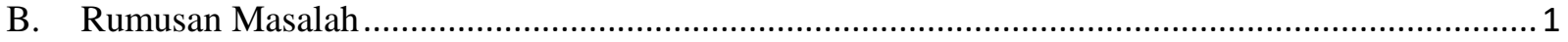

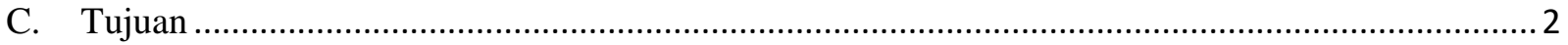

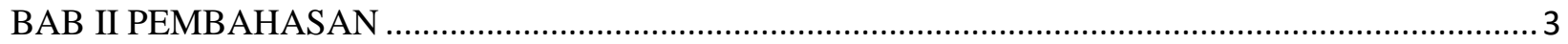

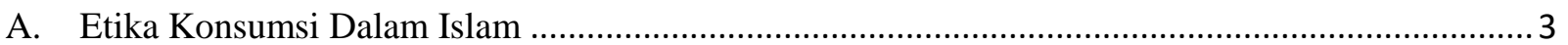

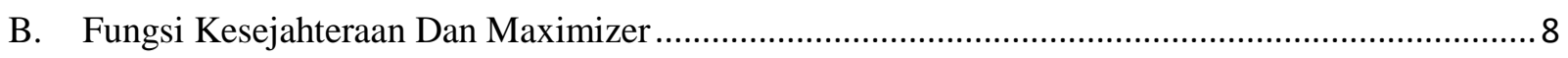

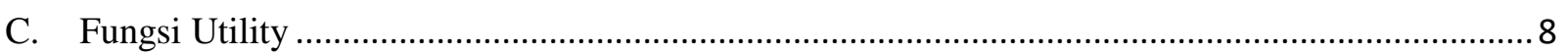

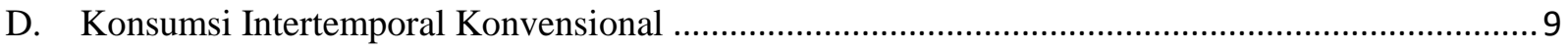

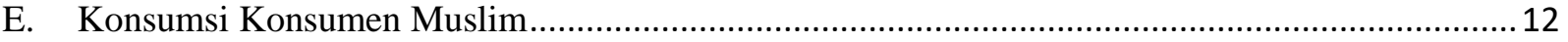

F. Hubungan Rasio Tabungan Dengan Pembelanjaan Akhir...................................................... 12

G. Hubungan Tabungan Dengan Investasi ................................................................................ 13

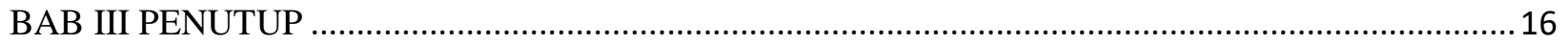

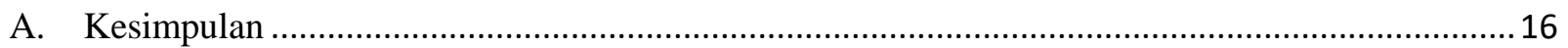

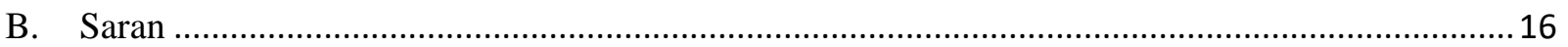

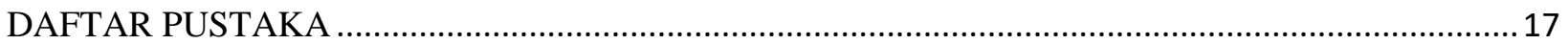




\section{BAB I \\ PENDAHULUAN}

\section{A. Latar Belakang}

Pengeluaran pemerintah merupakan salah satu variabel makroekonomi yang dilambangkan dengan huruf "C". Konsep konsumsi yang merupakan konsep yang di Indonesiakan dalam bahasa Inggris "Consumption", merupakan pembelanjaan yang dilakukan oleh rumah tangga ke atas barang-barang akhir dan jasa-jasa dengan tujuan untuk memenuhi kebutuhan dari orang-orang yang melakukan pembelanjaan tersebut atau juga pendapatan yang dibelanjakan. Bagian dari pendapatan yang tidak digunakan disebut tabungan dan ditandai dengan huruf "S" inisial dari kata saving. Apabila pengeluaran-pengeluaran konsumsi semua orang dalam suatu negara dijumlahkan, maka hasilnya adalah pengeluaran konsumsi masyarakat negara yang bersangkutan.

Pembelanjaan masyarakat atas makanan, pakaian, dan barang-barang kebutuhan mereka yang lain digolongkan pembelanjaan atau konsumsi. Komoditas yang diproduksi untuk memenuhi kebutuhan masyarakat disebut barang konsumsi. Kegiatan produksi ada karena ada konsumen, kegiatan konsumsi ada karena ada produsen, dan kegiatan produksi timbul karena adanya kesenjangan atau jarak antara konsumsi dan produksi. Prinsip dasar konsumsi adalah "Selama anggaran saya mencukupi dan saya mendapatkan kepuasan terbesar, saya akan mengkonsumsi semuanya".

Ada banyak alasan mengapa analisis ekonomi makro memerlukan perhatian mendalam terhadap konsumsi rumah tangga. Alasan pertama adalah bahwa konsumsi rumah tangga memberikan pendapatan bagi pendapatan nasional. Di sebagian besar negara, pengeluaran konsumen menyumbang sekitar 60-75\% dari pendapatan nasional. Alasan yang kedua, konsumsi rumah tangga mempunyai dampak dalam menentukan fluktuasi kegiataan ekonomi dari satu waktu ke waktu lainnya. Konsumsi seseorang berbanding lurus dengan pendapatannya. Semakin banyak pendapatan yang dimiliki seseorang, semakin banyak pengeluaran konsumen. Rasio pengeluaran konsumen untuk pendapatan tambahan adalah keinginan marjinal untuk mengkonsumsi (Marginal Propensity to Consume, MPC). Besarnya pendapatan tambahan tersebut disebut dengan keinginan marginal untuk menabung (marginal to save, MPS). Pengeluaran konsumsi rumah tangga memiliki konsumsi rumah tangga minimum, yaitu pengeluaran konsumsi, meskipun tidak ada pendapatan. Pengeluaran konsumsi rumah tangga ini disebut pengeluaran konsumsi otonom.

Pertumbuhan ekonomi saat ini bertumpu pada konsumsi karena peranan sektor investasi dan ekspor mendorong pertumbuhan ekonomi. Berangkat dari latar belakang permasalahan di atas, penulis mengkaji dan menganalisis faktor-faktor yang dapat mempengaruhi konsumsi masyarakat Indonesia. Oleh karena itu, kami akan membahas secara rinci latar belakang yang dapat kami berikan dalam diskusi.

\section{B. Rumusan Masalah}

1. Bagaimana etika konsumsi dalam islam itu?

2. Apa saja fungsi dari kesejahteraan dan maximizer? 
3. Apa saja fungsi utility?

4. Bagaimana konsumsi intertemporal konvensional itu?

5. Bagaimana konsumsi konsumen muslim itu?

6. Bagaimana hubungan rasio tabungan dengan pembelanjaan akhir?

7. Bagaima hubungan tabungan dengan investasi?

\section{Tujuan}

1. Mengetahui etika konsumsi dalam islam

2. Mengetahui fungsi dari kesejahteraan dan maximizer

3. Mengetahui fungsi utility

4. Mengetahui konsumsi intertemporal konvensional

5. Mengetahui konsumsi konsumen muslim

6. Mengetahui hubungan rasio tabungan dengan pembelanjaan akhir

7. Mengetahui hubungan tabungan dengan investasi 


\section{BAB II \\ PEMBAHASAN}

\section{A. Etika Konsumsi Dalam Islam}

1. Batasan dalam konsumsi menurut Islam

Secara bijaksana al-Qur'an telah menginformasikan suatu larangan berdimensi sosial untuk kesejahteraan manusia agar harta tidak hanya dimiliki oleh segelintir orang saja. Larangan dalam pembelanjaan harta melingkupi dua macam, antara lain:

Pertama, larangan bersikap kikir/bakhil dan menumpuk harta. Kesadaran akan penderitaan yang dialami oleh mereka yang membutuhkan adalah bagian besar dari Islam. Keseimbangan yang diciptakan Allah dalam bentuk aturanaturan yang bersifat komprehensif dan universal yaitu al-Qur'an dalam konteks hubungan sosial, apabila diimplementasikan dengan mengambil contoh para nabi, rasul dan orang-orang yang beriman (As salaf sholeh) berdampak pada pemerataan tingkat kesejahteraan. Sikap kikir sebagai salah satu sifat buruk manusia harus dikikis dengan menumbuhkan kesadaran bahwa harta adalah amanah Allah swt yang harus dibelanjakan sebahagian dari harta tersebut kepada orang-orang yang berhak mendapatkannya.

Larangan kikir terhadap harta membuktikan dalam sifat ini menunjukkan kurangnya nilai kepekaan sosial, manusia sebagai makhluk sosial (Homo Hominy Lupus), di sisi lain, tidak hanya hidup sendiri, tetapi juga membutuhkan bantuan orang lain, tanpa interaksi langsung. Sikap kikir membuat orang menjadi sombong dan bangga dengan anggapan bahwa meskipun Allah SWT, harta yang mereka miliki adalah hasil jerih payah sendiri tanpa bantuan sedikit pun dari pihak lain. Sebagai pemilik alam semesta dan isinya, ia termasuk milik manusia.Allah swt berfirman:

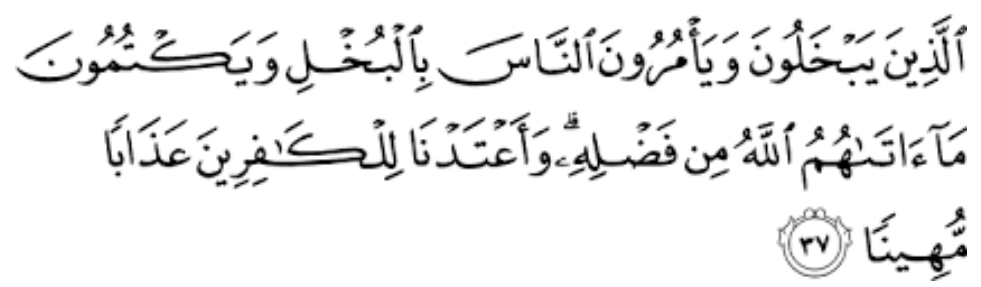

"(yaitu) orang-orang yang kikir, dan menyuruh orang lain berbuat kikir, dan menyembunyikan karunia Allah yang Telah diberikan-Nya kepada mereka. dan kami telah menyediakan untuk orang-orang kafir siksa yang menghinakan. (QS. An-Nisaa: 37)

Asbab an nuzul Diriwayatkan oleh Ibnu Abi Hatim dari Sa'id bin Jabir berkata:

"Dulu ulama dari kalangan bani Israil kikir terhadap ilmu yang mereka miliki". Ibnu Abbas berkata: "Sekelompok orang (diantaranya:

Ka'ab bin Asyraf, Usamah bin Habib, dan Nafi' bin Abi Nafi') mendatangi seorang pemuda anshar. Sekelompok orang tersebut saling memberi nasehat agar jangan menginfaqkan harta, karena takut akan fakir, dan jangan terburu-buru dalam mengeluarkan harta, karena tidak tau apa yang akan terjadi.Label sombong yang diberikan oleh Allah swt. kepada orang-orang yang kikir, kalau ditelaah lebih jauh lagi membawa paradigma baru 
(pelaksanaan nilainilai Islami) menuju pemerataan kesejahteraan dengan meninggalkan paradigma lama (sikap kikir) ${ }^{1}$.

Sikap kikir tumbuh dari perilaku menumpuk-numpuk harta dan menghitung-hitung harta tersebut serta mempunyai anggapan bahwa harta tersebut dapat mengekalkan hidupnya. Allah memperingatkan dalam alQur'an yang artinya:

"Kecelakaan bagi setiap pengumpat lagi pencela, yang mengumpulkan harta dan menghitunghitungnya. Dia mengira hartanya itu dapat mengekalkannya. Sekali-kali tidak! Sesungguhnya dia benar-benar akan dilemparkan ke dalam huthanah."

(QS. Al-Humazah: 1 - 4)

Sifat kikir yang kelewat batas (syuhun mutho') meskipun Allah menyukai bukti kegembiraan yang terlihat pada hamba-hamba-Nya, sikapnya terhadap keegoisan terhadap dirinya sendiri juga licik. Maka siapa saja yang kikir terhadap dirinya dan keluarganya akan semakin kikir terhadap kerabat, fakir miskin, anak yatim, dan sebagainya. Imam at Thobari berkata:

"Nafkah dimulai dari keluarga termasuk didalamnya dirimu sendiri. Memberi nafkah kepada pribadi termasuk kewajiban yang besar dibanding menafkahi keluarga. Tidak seharusnya seorang menghidupkan orang lain dengan cara merusak diri sendiri". ${ }^{2}$

Kedua, larangan berlebihan dan pemborosan. Islam membenarkan pemeluknya untuk menikmati kebaikan dunia. Prinsip ini berbeda dengan sistem kerahiban, manuisme parsi, sufuisme brahma dan sistem lain yang sinis terhadap dunia.. ${ }^{3}$ Hidup sederhana adalah tradisi Islam yang mulia, baik dalam membeli makanan, minuman, pakaian, rumah dan segala apapun, bahkan Rasulullah melarang boros berwudhu dengan air walaupun berada di sungai yang mengalir. ${ }^{4}$

"Rasulullah bertemu Sa'ad ibn Abi waqqos saat berwudhu,dan bersabda :"Kenapa engkau berlebih lebihan?", Sa'ad bertanya:"Apakah dalam berwudhu ada sikap berlebihan?", beliau bersabda ;"Ya ada, walaupun engkau berwudhu di disungai yang mengalir". (HR Ibnu Majah)

"Hai anak Adam, pakailah pakaianmu yang indah setiap (memasuki) mesjid, makan, minumlah, dan jangan berlebih-lebihan. Sesungguhnya Allah tidak menyukai orang-orang yang berlebihlebihan." (Qs. Al-A'raf: 31)

Beberapa ulama salaf mengatakan bahwa Allah swt. menjelaskan rahasia kesehatan pada pertengahan ayat ini (makanlah dan minumlah dan jangan berlebih-lebihan) ${ }^{5}$. Penulis memahami kesehatan dalam dua dimensi fisik maupun financial.

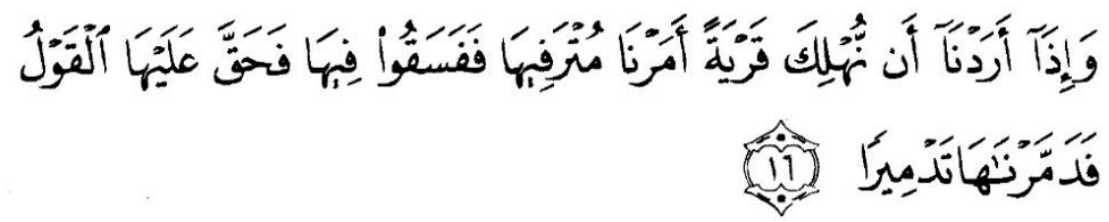

${ }^{1}$ Lihat Qs. 4:36-37, 3:180, 9:34-35, 70:15-18, 92:811, dan 47:36-38).

${ }^{2}$ Lihat, Fathu al Bari, jld 11 hlm 427.

${ }^{3}$ Lihat Yusuf Qardhawi, norma dan etika ekonomi Islam, hlm 148.

${ }^{4}$ Hadist riwayat Ibnu Majah, hadist no. 425.

${ }^{5}$ Lihat: Tafsir Al quran Al A'zhim,surat al a'raf ayat31, Ibnu Katsir, Riyadh: Darus salam, jld3 hlm 406. 
"Dan jika Kami hendaki membinasa-kan suatu negeri, Kami perintahkan kepada orang-orang yang hidup mewah di negeri itu (supaya mentaati Allah) tetapi mereka melakukan kedurhakaan dalam negeri itu, maka sudah sepantasnya berlaku terhadap-nya perkataan (ketentuan Kami), kemudian Kami hancurkan negeri itu sehancur-hancurnya." (Qs. Al Isro: 16)

Firman Allah di atas merupakan hukum Allah terhadap orang-orang yang bermewahmewahan tanpa memberikan kewajiban kepada yang berhak menerimanya. Pola hidup yang dijalankan atas dasar bermewah-mewahan sehingga tidak segan-segan menindas golongan miskin dan lemah untuk keuntungan individual bahkan tidak peduli terjadinya penderitaan pada orang lain, oleh karena itu orang kaya bertambah kaya dan orang miskin akan semakin miskin, alur dari problematika tersebut akan mendorong terganggunya keutuhan masyarakat. Islam mencegah terjadinya penumpukan harta pada seseorang atau kelompok tertentu, agar di putar sehingga manfaat dan kebaikan dirasakan masyarakat secara luas dan menghimbau setiap orang untuk membelanjakannya dalam hal-hal yang ma'ruf. Ketiga ayat tentang berlebihan di atas secara tegas memberikan arahan untuk menghindari sikap berlebih-lebihan dan bermegahmegahan dalam hidup. Selain merusak individu, sikap bermewah mewahan juga merusak masyarakat. Merusak individu karena yang dikejar didunia, tidak lebih daripada kepuasan nafsu birahi dan kepuasan perut. Mereka melalaikan norma dan etika. Nafsu mereka membunuh semangat juang, membunuh kesungguhan usaha, membunuh kerelaan hidup bersusah payah dan menjadikannya hamba bagi kemegahan. Kemewahan juga merusak masyarakat karena golongan yang hidup mewah menindas hak golongan lainnya dengan kemewahannya ${ }^{6}$.

Harta karunia Allah untuk manusia yang harus disyukuri. Bentuk rasa syukur kita bisa dinilai dari derajat sikap kita terhadap amanah. Sebagai amanah maka dipastikan Allah akan meminta pertanggungjawaban atas penyikapan kita dalam pembelanjaannya (Tsumma latussalunna 'anin na'iim).

Bahkan dalam masalah harta secara khusus Rasulullah saw. menjelaskan bahwa seseorang akan ditanya dari mana dia mendapatkannya (min aina iktasaba) dan untuk apa dibelanjakan (fii maa anfaqa). Seorang muslim yang rasional yaitu yang beriman semestinya anggaran konsumsi ibadahnya harus lebih banyak dibandingkan anggaran konsumsi duniawinya. Karena memaksimalkan kemenangan (falah) adalah tujuannya. Sebaliknya, semakin tidak masuk akal, semakin kufur, sehingga anggaran konsumsi sekuler akan semakin besar, dan tujuan falah tidak akan tercapai pada akhirnya. Oleh karena itu, membeli mobil Lamborghini dalam kondisi lalu lintas yang padat, banjir, dan macet, membeli tas Hermes dengan harga hingga 1 miliar untuk menyesuaikan gaya hidup, membeli pakaian di Paris untuk gengsi, dan lain-lain bukanlah akhlak konsumen yang islami. Islam mengutamakan akhlak, mengatur pola konsumsi umatnya, dan mencapai keseimbangan konsumsi yang menyeluruh antara individu dengan masyarakat luas, dunia dan akhirat.

2. Prinsip Konsumsi Dalam Islam

Menurut $\mathrm{Al} \mathrm{Haritsi}^{7}$ mengutip kebijakan Umar ibn Khottob radhiyallahu anhu tentang prinsip komsumsi dalam Islam adalah :

\footnotetext{
${ }^{6}$ Yusf qardhawi,Norma dan etika dalam ekonomi Islam, hlm 152.

${ }^{7}$ Jaribah bin Ahmad Al-Haritsi, Fikih Ekonomi
} 
a. Prinsip syari'ah bahwa komsumsi merupakan sarana untuk membangun keta'atan pada Allah swt. dan harus mengetahui betul apa yang dikomsumsinya baik dari sisi zat, proses pembuatan (halal dan haram).

b. Prinsip kuantitas bahwa kesederhanaan dalam segala hal merupakan kebaikan dengan memperhatikan kemampuan dan pendapatan dalam mengkomsumsi barang dan jasa serta berupaya untuk menabung dan menginvestasikan hartanya.

c. Prinsip prioritas bahwa pertimbangan komsumsi perlu mendahulukan kebutuhan primer kemudian sekunder kemudian tertier.

d. Prinsip sosial adalah bahwa semangat kerjasama adalah semangat timbal balik dan memberi contoh perilaku konsumen dan memperhatikan kepentingan umum untuk tidak membahayakan atau merugikan orang lain atau mengganggu ketertiban umum.Kaidah lingkungan bahwa perhatian kepada sumber daya alam yang ada dengan tidak mengexploitasi tanpa batas dan merusaknya.

Menurut Abdul Mannan, ada 5 prinsip konsumsi dalam islam ${ }^{8}$ :

a. Prinsip Keadilan, prinsip ini mengandung arti ganda mengenai mencari rizki yang halal dan tidak dilarang hukum.

b. Prinsip Kebersihan, Makanan harus enak dan cocok untuk dimakan, tidak merusak noda atau menjijikkan.

c. Prinsip Kesederhanaan, prinsip ini mengatur perilaku manusia tentang makan dan minum yang sopan. Maksudnya: tiap-tiap akan mengerjakan sembahyang atau thawaf keliling ka'bah atau ibadat-ibadat yang lain. Dengan tidak melampaui batas yang dibutuhkan oleh tubuh dan jangan pula melampaui batas-batas makanan yang dihalalkan.

d. Prinsip kemurahan hati, dengan mentaati perintah Islam tidak ada bahaya maupun dosa ketika kita memakan dan meminum makanan yang diberikan Allah.

e. Prinsip moralitas, seorang muslim diajarkan untuk menyebut nama Allah sebelum makan dan menyatakan kesyukurannya kepadaNya setelah makan.

\section{Kebutuhan Dan Keinginan}

Seperti yang kita pahami dalam pengertian ekonomi tradisional, ekonomi pada dasarnya membuat pilihan tentang penggunaan sumber daya yang terbatas untuk memenuhi (pada dasarnya tidak terbatas) kebutuhan barang dan jasa.Mempelajari upaya manusia baik sebagai individu maupun komunitas. Kekurangan barang dan jasa terjadi ketika kebutuhan orang dan masyarakat (wants) lebih besar dari ketersediaan barang dan jasa tersebut. Oleh karena itu, kekurangan ini terjadi ketika barang atau jasa tidak cukup untuk memenuhi kebutuhan dan keinginan tersebut.

Ilmu ekonomi tradisional sepertinya tidak membedakan antara kebutuhan dan keinginan. Karena jika tidak terpenuhi, keduanya akan menimbulkan efek yang sama, yaitu kelangkaan. Dalam hal ini, Imam al-Ghazali tampaknya telah dengan jelas membedakan keinginan (raghbah dan keinginan) dan kebutuhan (hajat), yang kelihatannya sepele, tetapi berdampak besar bagi

\footnotetext{
${ }^{8}$ Abdul Mannan,Teori dan Praktek dasar dasar Ekonomi Islam.
} 
ekonomi. Dari perspektif pemisahan antara keinginan (want) dan kebutuhan (need), perbedaan antara ekonomi Islam dan ekonomi tradisional akan sangat jelas.

Menurut Imam al-Ghazali kebutuhan (hajat) adalah keinginan manusia untuk mendapatkan sesuatu yang diperlukan dalam rangka mempertahankan kelangsungan hidupnya dan menjalankan fungsinya. Misalnya, kita melihat kebutuhan akan sandang dan pangan. Kebutuhan makanan adalah untuk menolak kelaparan dan melangsungkan kehidupan, kebutuhan pakaian untuk menolak panas dan dingin. Pada tahapan ini mungkin tidak bisa dibedakan antara keinginan (syahwat) dan kebutuhan (hajat) dan terjadi persamaan umum antara homo economicus dan homo Islamicus. Akan tetapi, tujuan utama manusia menciptakan nafsu makan adalah menggerakkannya mencari makanan untuk menutupi rasa lapar, sehingga menjaga kesehatan fisik manusia dan beribadah kepada Allah. Di sinilah letak perbedaan mendasar antara filosofi yang melandasi teori permintaan Islami dan konvensional. Islam selalu mengaitkan aktivitas pemenuhan kebutuhan dengan tujuan utama penciptaan manusia. Ketika manusia melupakan tujuan penciptaannya, maka hakikatnya tidak berbeda dengan hewan ternak, yang hanya makan karena lapar.Aplikasi Teori komsumsi Islami.

a. Korelasi Positif Antara Hidup Sederhana dan Tingkat Kesejahteraan

Didalam ekonomi mikro, kita mengenal istilah budget constrain (batas anggaran). Dimana seseorang mempunyai batas anggaran minimal dalam membelanjakan hartanyaSetiap keinginan pasti memiliki batasan yang membatasinya, dan tentunya batasan ini sangat dipengaruhi oleh kemampuan dan usaha yang dikeluarkan untuk mendapatkan batasan yang tinggi tersebut.

Semangat hidup sederhana sangat membantu konsumen muslim untuk merasa puas karena tidak berlebihan.Dengan gaya hidup seperti itu maka seseorang akan merasa puas dengan apa yang ada bahkan dapat menyisihkan sisa anggarannya untuk di tabung (reserve). Sehingga pola hidup yang konsumtif dapat diganti dengan pola investasi yang dapat meningkatkan kesejahteraan dalam hal materi.

\section{b. Konsumsi Halal dan Thoyyib dengan Tingkat Kesehatan Masyarakat}

Lazim dipahami dalam teori ekonomi, bahwa peningkatan permintaan suatu produk akan berpengaruh terhadap peningkatan usaha penyedia (Supply Side) produk tersebut. Dalam Islam bahwa halal itu jelas begitu juga dengan haram. Setiap yang diharamkan oleh Allah swt. pasti mengandung mudharat/kerusakan bagi manusia itu sendiri begitu juga sebaliknya.

Misalnya, kebanyakan ulama melarang merokok karena merokok membawa banyak kerugian, alkohol dapat merusak otak dan jaringan penting manusia, perjudian dapat menyebabkan ketidakadilan/merugikan satu pihak, dan sebagainya. Oleh sebab itu pentingnya kesadaran masyarakat untuk menghindari produk-produk yang haram dapat meningkatkan kesejahteraan kesehatan masyarakat yang jangka panjangnya dapat melahirkan generasigenerasi yang sehat secara jasmani maupun rohani. Begitu juga dengan supply produk halal yang akan terus meningkat, disebabkan oleh kesadaran masyarakat akan konsumsi produk halal dan thoyyib sehingga permintaan akan produk tersebut pun meningkat.

\section{c. Kedermawanan Akan Melahirkan Produktivitas Ekonomi}

Islam memuji orang-orang yang benar-benar dermawan dan mengutuk sikap pelit. Prilaku dermawan adalah prilaku mulia yang sangat didorong oleh Islam. Banyak dalil AlQur'an dan Hadits yang memotivasi manusia untuk menyuburkan prilaku kedermawanan 
dalam kehidupan. Kedermawanan juga dapat menggairahkan aktivitas ekonomi, dikarenakan orang yang mempunyai daya beli (Purchasing Power) akan mensuply orang-orang yang tidak mempunyai daya beli, dengan itu ekonomipun akan bergerak kearah yang positif.

\section{B. Fungsi Kesejahteraan Dan Maximizer}

Fungsi Kesejahteraan dan maximizer dalam Islam pandangan Al-Ghazali. Abu Hamid Ahmad bin Muhammad al- Ghazali at-Thusi lahir di Tus sekarang Meshed, sebuah kota kecil di Khurasan, sekarang bernama Iran, pada tahun 450 H $(1058 \mathrm{M})$ dan meninggal 505 H $(1111 \mathrm{M})$ pada tempat yang sama. Beliau dijuluki Hujjatul Islam

Fungsi Kesejahteraan, Menurut Al-Ghazali, kesejahteraan suatu masyarakat tergantung kepada pencarian dan pemeliharaan lima tujuan dasar:

- 1) agama (al-dien),

-2) hidup atau jiwa (nafs),

-3) keluarga atau keturunan (nasl),

-4) harta atau kekayaan (maal), dan

-5) intelek atau akal (aql).

Tiga alasan Al Ghazali mengapa seseorang harus terlibat dalam kegiatan ekonomi

1. mencukupi kebutuhan hidup yang bersangkutan,

2. mensejahterakan keluarga,

3. membantu orang yang membutuhkan.

Maximizer Al-Ghazali melihat manusia sebagai penambah (selalu menginginkan yang maksimal) dan selalu menginginkan lebih.

\section{Fungsi Utility}

Teori ekonomi konvensional mengambarkan tingkat kepuasan seseorang terhadap suatu barang/jasa demi memuaskan keinginannya sebagai utilitas. Kegiatan ekonomi menghasilkan sesuatu didorong oleh utilitas dalam hal itu. Manakala sesuatu itu memiliki kegunaan bagi seseorang maka ia akan melakukan aktivitas untuk mengkonsumsi sesuatu itu. Utilitas juga menggambarkan nilai guna atas suatu barang. Jadi, suatu produk/jasa memiliki satuan nilai yang dapat diukur dengan fungsi utilitas.

Fungsi utilitas diwakili oleh kurva indiferen. Fungsi utilitas juga merepresentasikan kepuasan ketika mengkonsumsi sejumlah barang/jasa. Semakin banyak jumlah yang dikonsumsi, maka akan semakin besar pula tingkat kepuasan yang didapatnya. Tapi ini tidak terjadi selamanya. Teori utilitas juga mengetahui konsep pengurangan utilitas marjinal, yang menjelaskan pengurangan kepuasan (utilitas) dengan setiap penambahan yang diberikan. Ini juga berarti bahwa ada kepuasan maksimum secara keseluruhan dengan konsumsi barang/jasa. Selain teori di atas, ada beberapa teori turunan yang menjelaskan tentang fungsi utilitas. 
Dalam perkembangannya, teori utilitas menyebabkan munculnya gerakan-gerakan ideologis seperti aliran utilitarianisme (utilitarianisme). Utilitarianisme membutuhkan upaya pemerintah untuk memaksimalkan utilitas total setiap anggota masyarakat dengan mendistribusikan pendapatan dari yang kaya ke yang miskin. Selain itu, ada sekolah liberal dan liberal di mana tidak ada perbedaan yang signifikan antara utilitarianisme dan pemikiran mereka, yang membutuhkan upaya untuk memaksimalkan utilitas keseluruhan setiap anggota masyarakat.

\section{Konsumsi Intertemporal Konvensional}

Pembahasan tentang konsumsi sudah ada pada masalah teori konsumsi Islam. Akan tetapi dalam pembahasan tersebut kita baru membahas dalam suatu waktu saja. Padahal, perilaku konsumen kita juga bergantung pada ekspektasi atau ekspektasi kita di masa depan dan permintaan konsumen.

Yang dimaksud dengan konsumsi inter-temporal adalah konsumsi yang dilakukan dalam dua waktu, yaitu masa sekarang (periode pertama) dan masa yang akan datang (periode kedua). Dalam ekonomi konvensional, pendapatan adalah jumlah konsumsi dan tabungan. Atau secara matematis ditulis: $\mathrm{Y}=\mathrm{C}+\mathrm{S}$ Di mana:

$\mathrm{Y}=$ pendapatan

$\mathrm{C}=$ konsumsi

$\mathrm{S}=$ tabungan

Misalkan pendapatan, konsumsi, tabungan pada periode pertama adalah $\mathrm{Y} 1, \mathrm{C} 1, \mathrm{~S} 1$ dan pendapatan, konsumsi dan saving pada periode kedua adalah Y2, C2 dan S2 maka persamaan di atas dapat dituliskan sebagai berikut:

Pendapatan pada periode pertama adalah:

$\mathrm{Y} 1=\mathrm{C} 1+\mathrm{S} 1$

Pendapatan pada periode kedua adalah:

$\mathrm{Y} 2=\mathrm{C} 2+\mathrm{S} 2$

Apabila konsumsi di periode pertama lebih kecil daripada pendapatan, maka akan terjadi saving dan konsumsi di periode kedua semakin besar.

$\mathrm{Y} 1=\mathrm{C} 1+\mathrm{S} 1$ dan $\mathrm{C} 1<\mathrm{Y} 1$

$\mathrm{Y} 2=\mathrm{C} 2+\mathrm{S} 2$

$=(\mathrm{C} 2+\mathrm{S} 1)+\mathrm{S} 2$

Bila kita mengasumsikan konsumsi periode satu (C1) dan dua (C2) ditentukan oleh besarnya nominal uang (m) yang ada di tangan maka (C1) dipenuhi oleh (m1) dan (C2) dipenuhi oleh (m2) . Maka apabila kita asumsikan sejumlah uang yang tersedia pada periode pertama dan kedua dialokasikan sepenuhnya untuk konsumsi pada periode satu dan dua serta tidak ada bunga atau value added dari volume uang untuk periode kedua (m2), maka budget constraint ( batas anggaran) untuk mengonsumsi pada periode satu dan dua dapat dilihat pada gambar berikut. 


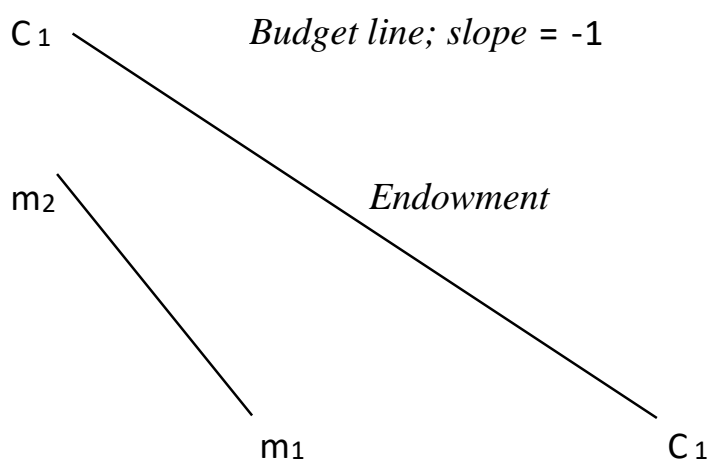

Apabila pendapatan dari sejumlah nominal uang kita didefinisikan ke dalam dua kelompok; konsumsi dan saving, maka berdasarkan persamaan di atas dapat diketahui bahwa semakin besar konsumsi pada periode pertama C1, akan semakin kecil saving S1 dan konsumsi periode kedua C2. Jika tidak ada perubahan konsumsi baik pada periode 1 maupun periode 2 dan tidak ada pinjaman atau bunga dan pengembalian investasi, maka konsumsi yang dihasilkan pada periode 1 yaitu $\mathrm{C} 1=\mathrm{m} 1$ dan periode 2 adalah $\mathrm{C} 2=\mathrm{m} 2$. Namun, jika pinjaman dilakukan pada periode 1 dan pinjaman digunakan untuk meningkatkan konsumsi $\mathrm{C} 1$, maka jumlah barang yang dikonsumsi pada periode tersebut adalah:

$\mathrm{C} 1=\mathrm{m} 1+\Delta(\mathrm{m} 2-\mathrm{C} 2)$

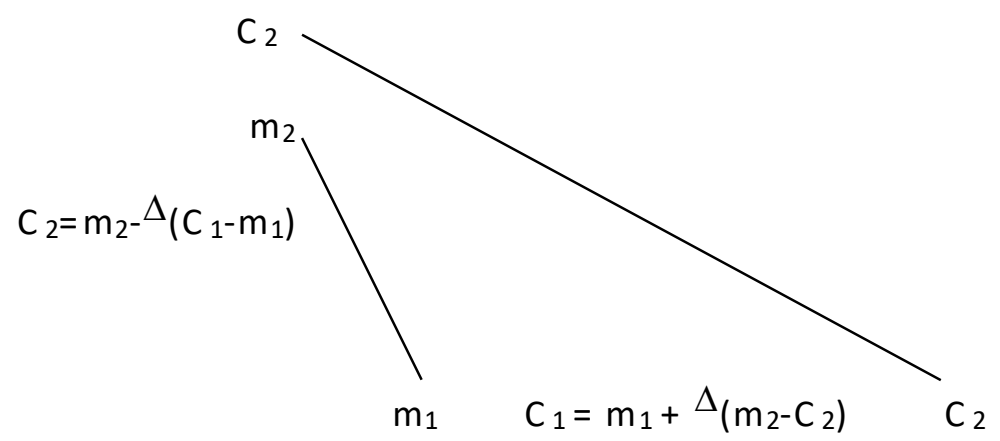

Pada gambar di atas menunjukan bahwa besarnya konsumsi juga dipengaruhi oleh posisi konsumen, apakah mengeluarkan pengeluaran yang berbeda di antara periode atau tidak.pada prinsipnya prilaku konsumen di mana terjadi selisih antara pendapatan dengan jumlah uang yang digunakan untuk konsumsi, dapat dibagi menjadi tiga:

1. Lender, di mana total lebih kecil daripada pendapatan.

2. Borrower, di mana total konsumsi lebih besar dari pendapatan.

3. Polonius poin, di mana total konsumsi sama dengan total pendapatan. 

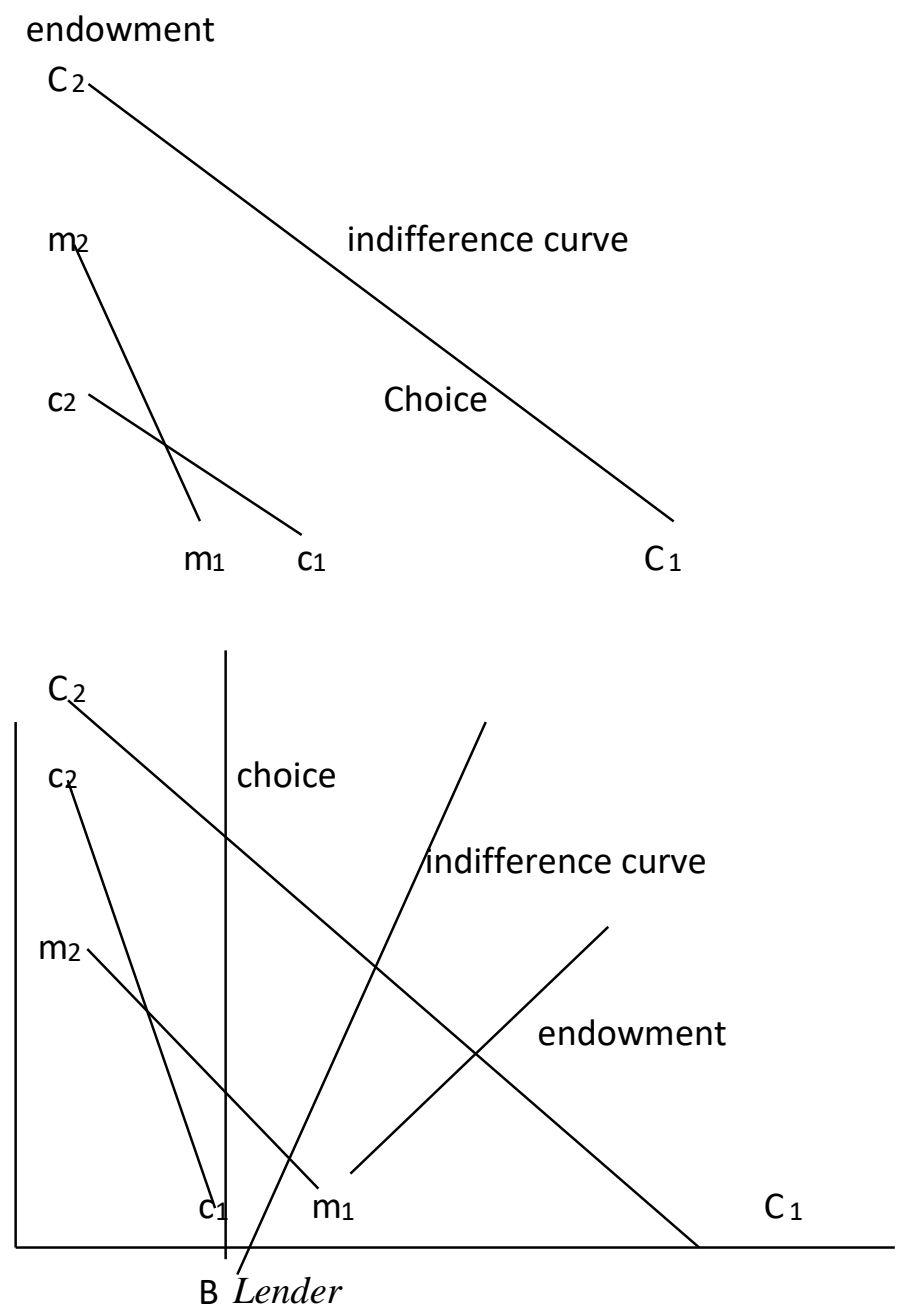

Titik optimal untuk konsumen berada pada perpotongan kurva indifference dengan budget line yang tersedia. Posisi dan posisi kurva indiferen sangat bergantung pada perspektif konsumen dan tingkat permintaan. Pada gambar a, di mana konsumen berperilaku sebagai borrower, perpotongan kurva indefference menyebabkan konsumsi pada masa kini C1 lebih tinggi dari pada konsumsi untuk masa depan $\mathrm{C} 2$, karena jumlah uang yang tersedia pada saat ini hanya $\mathrm{m} 1$ di mana $\mathrm{m} 1<\mathrm{C} 1$, maka ada sebagian dari uang yang disediakan untuk konsumsi yang di masa datang $\mathrm{m} 2$ digunakan untuk mengomsumsi pada masa sekarang sehingga untuk mencapai tingkat konsumsi C1 >C2 maka konsumen akan meminjam uang dari piha (Samsul, 2019)k lain dengan jaminan sebagian dari $\mathrm{m} 2$ akan digunakan untuk membayar hutang tersebut.

Penjelasan di atas juga dapat kita gunakan untuk menerangkan bagaimana perilaku konsumen ketika bertindak sebagai lender. Tidak dikenakan bunga atau bagi hasil, sehingga sebagian dari jumlah nominal $\mathrm{m} 1$ tidak akan digunakan untuk menanggung barang tersebut. Akan tetapi pengorbanan $\mathrm{m} 1$ ini akan dinikmati di masa datang sehingga $\mathrm{C} 2=\mathrm{m} 2+\Delta(\mathrm{m} 1-\mathrm{C} 1)$.

Tentu akan berbeda dapat $\mathrm{C} 2$ akan berbeda dampak $\mathrm{C} 2$ apabila $\mathrm{m} 1$ yang disimpan memberikan tambahan nominal uang pada periode 2. Misalnya $\mathrm{m} 1$ yang ditangguhkan untuk ditabung S1 disimpan dengan pemberlakuan sistem bunga, maka saving yang terjadi pada periode 1 akan memberikan nilai lebih sebesar bunga, sehingga persamaan konsumsi pada periode 2 menjadi:

$$
\mathrm{C} 2=\mathrm{Y} 2+\mathrm{r}(\mathrm{S} 1)
$$




$$
\begin{aligned}
& =\mathrm{Y} 2+(\mathrm{Y} 1-\mathrm{C} 1)+\mathrm{r}(\mathrm{Y} 1-\mathrm{C} 1) \\
& =\mathrm{Y} 2+(1+\mathrm{r})(\mathrm{Y} 1-\mathrm{C} 1)
\end{aligned}
$$

\section{E. Konsumsi Konsumen Muslim}

Konsumsi dalam ekonomi Islam atau konsumsi masyarakat muslim dinilai sebagai sarana yang wajib bagi seorang muslim tidak bisa mengabaikannya, konsumsi seorang muslim yaitu sebagai sarana ketaatan dalam beribadah kepada AllahTa'ala. Konsumen muslim bertujuan untuk mencapai suatu maslahah. (Samsul, 2019)

Sebelum kita melanjutkan pembahasan kita tentang konsumsi konsumen muslim, perlu dikembangkan asumsi dasar.

1) Sistem ekonomi saat ini menerapkan aturan kondisi Islam dan kebanyakan orang percaya pada masyarakat Islam dan menjadikannya bagian integral dari setiap aktivitas dalam kehidupan mereka.

2) Lembaga zakat telah menjadi bagian dari sistem ekonomi, dan hukumnya wajib bagi setiap orang yang mampu.

3) Pelarangan riba dalam setiap aktifitas ekonomi.

4) Prinsip mudharabah dan kerjasama diaplikasikan dalam perekonomian.

5) Tersedianya instrumen moneter Islam dalam perekonomian.

6) Konsumen memiliki perilaku yang memaksimalkan kepuasannya.

Dalam konsep Islam, konsumsi berarti memiliki pendapatan yang tidak hanya digunakan untuk mengkonsumsi sesuatu, tetapi juga pendapatan yang digunakan untuk berjuang di jalan Allah atau yang lebih dikenal dengan infaq. Sehingga persamanya dapat ditulis sebagai berikut:

$\mathrm{Y}=(\mathrm{C}+$ Infak $)+\mathrm{S}$

Persamaan ini disederhanakan menjadi

$\mathrm{Y}=(\mathrm{C}+$ Infak $)+\mathrm{S}$

$\mathrm{Y}=\mathrm{FS}+\mathrm{S}$

Keterangan: $\mathrm{Y}$ : pendapatan

$\mathrm{C}$ : konsumsi

$\mathrm{S}$ : investasi / tabungan

FS :final spending (konsumsi yang dibelanjakan untuk keperluan konsumtif ditambah dengan pembelanjaan untuk infak)

Dimana FS (Final Spending) konsumsi untuk keperluan konsumsi ditambahkan pada pengeluaran infaq. Sehingga final spending adalah pembelanjaan akhir seorang konsumen muslim.

\section{F. Hubungan Rasio Tabungan Dengan Pembelanjaan Akhir}

Rasio tabungan adalah jumlah pengeluaran yang dialokasikan untuk tabungan atau investasi dibandingkan dengan pendapatan setiap bulannya. Jadi jika setiap bulan bapak X memiliki pendapatan sebesar Rp10.000.000 dan mengalokasikan pendapatan sebesar Rp500.000 untuk tabungan maka Bapak X memiliki rasio tabungan sebesar 5\%.

Menabung atau berinvestasi adalah cara kita untuk meningkatkan daya beli di masa yang akan datang, jadi sebaiknya ada alokasi rutin untuk tabungan/investasi setiap bulan. Idealnya 
rasio tabungan ini sebesar minimal 10\% dari pendapatan. Semakin besar rasionya, semakin baik, dengan tetap memperhatikan kebutuhan atau pengeluaran yang lain.

Konsumsi adalah pembelanjaan atas barang dan jasa yang dilakukan oleh rumah tangga dengan tujuan untuk memenuhi kebutuhan dari orang yang melakukan pembelanjaan tersebut. Barang-barang yang diproduksi untuk digunakan oleh masyarakat guna memenuhi kebutuhannya dinamakan barang konsumsi. Suherman Rosyidi menyebut konsumsi sebagai penggunaan barang dan jasa yang secara langsung memenuhi kebutuhan manusia.

Rasio tabungan seseorang mengalami fluktuasi sepanjang siklus hiudpnya. Seseorang cenderung memperoleh penghasilan rendah pada usia muda, tinggi pada usia menengah, dan kembali menerima pendapatan rendah pada usia tua. Kecenderungan menabung pada usia muda berada pada titik negatif (disaving). Usia menengah, pendapatan digunakan untuk membayar pinjaman dan memulai tabungan. Kegiatan usia tua adalah mengambil tabungan pada disimpan saat usia menengah.

\section{G. Hubungan Tabungan Dengan Investasi}

Investasi dan tabungan adalah dua hal yang terpisah, tapi pada kondisi yang lebih makro, kedua hal itu menjadi kesatuan. Seorang yang berinvestasi sebenarnya dirinya telah menjalankan kegiatan menabung.

Untuk itu, tabungan tidak boleh terbatas pada tabungan bank, tetapi harus lebih luas. Menabung itu investasi, dan secara tradisional tabungan di perbankan itu investasi. Investa si jenis ini aman dan likuid atau mudah dicairkan. Kelemahannya adalah tingkat bunga sangat rendah. Tabungan dengan saldo di bawah Rp 15 juta, maka pendapatan bunganya akan lebih rendah dari biaya administrasi dan pajak. Oleh karena itu, tabungan setiap bulan akan berkurang.

Oleh karena itu, tabungan semacam ini tidak cocok sebagai sarana investasi, tetapi hanya sebagai sarana menabung. Belum lagi jika Anda memperhatikan nilai tabungan yang sebenarnya, yaitu dengan membandingkan nilai mata uang dengan kenaikan harga/tingkat inflasi, Anda akan mendapatkan nilai tabungan aktual yang negatif.

Tapi jangan ragu, karena ini tidak hanya terjadi di Indonesia, tapi juga di negara maju seperti Jepang. Suku bunga (deposito) di Jepang dengan tenor waktu 1 bulan sampai dengan 1 tahun berkisar 0,07\%-0,2\%, sedangkan laju inflasi berkisar 2,2\%/tahun. Dengan demikian nilai riil tabungan di Jepang berkisar minus $2 \%$ per tahun. Jika uang tersebut dibiarkan sebagai dana tabungan, maka jumlah uang tersebut akan tergerus.

\section{$\checkmark$ Beragam Bentuk Investasi}

Investasi selanjutnya adalah membeli surat berharga. Surat utang (obligasi, bond) menawarkan hasil/kupon yang lebih tinggi daripada tabungan dan menjamin pengembalian investasi. Namun berbeda dengan tabungan, jaminan ini masih merupakan peluang karena ada kemungkinan tidak dapat dikembalikan. Untuk itu, investor harus berhati-hati saat memilah.

Sebagai pemanis, investor dapat mengikat kondisi yang melindungi diri, seperti pemberian uang tunai secara berkala oleh debitur. Persyaratan ini dikenal sebagai aliansi pelindung. Setelah obligasi, saham merupakan alternatif bentuk investasi untuk jangka waktu yang lebih lama. Saham tidak menjanjikan pengembalian dan pengembalian modal. Karena itu, saham terkatagorilebih berisiko. Tentunya harapan imbalan dari saham lebih tinggi dibandingkan bond. Jika imbalan aktualnya lebih rendah Itulah risikonya. Baik bond dan saham kepemilikan 
dapat segera diakhiri dengan menjual pada harga pasar. Harga pasar ini biasanya mencerminkan prinsip-prinsip yang mendasari obligasi/saham penerbitJika investor masih memiliki kredit dalam jumlah tertentu, derivatif menjadi alternatif investasi berikutnya. Derivatif adalah investasi yang didasarkan pada transaksi aset (underlying) sebagai dasar perhitungan, namun dalam praktiknya, derivatif adalah investasi dengan margin atau uang muka, atau disebut juga dengan leverage. Jika besarnya marjin 10\%, maka berarti peluang laba adalah 1/marjin atau setara 10x (1000\%).

Dengan demikian, semakin kecil margin, semakin besar potensi keuntungan (juga potensi kerugian). Derivatif opsi, berinvestasi dengan membayar premi dan premi itu dibatalkan (habis). Potensi profitnya tentu fantastis, setara dengan 1/margin.

Dengan demikian, jika modal investasi masih ada dalam tabungan, obligasi dan saham, maka tidak ada lagi tabungan dalam derivatif keuangan (opsi). Anda juga perlu memahami bahwa profitabilitas berbanding lurus dengan risiko. Jika ada investasi menjanjikan imbalan sangat tinggi (misal 100-1000\%) per tahun, itu artinya investor harus siap menanggung risiko.

Sederhananya orang tersebut tidak memanfaatkan sarana ini. Cara lain untuk mengetahui apakah sektor perbankan terlibat dalam pembiayaan usaha/investasi ini. Bank biasanya menerapkan manajemen risiko yang ekstensif dalam hal penyaluran kredit.

Beberapa orang menghemat asuransi. Hal ini kurang tepat. Asuransi pada dasarnya adalah dana penjaminan untuk kondisi yang tidak diinginkan. Jadi jenis asuransi adalah pengendalian risiko pada tingkat yang dapat diterima. Investasi di sini kedaluwarsa (habis) demi kenyamanan.

Jadi imbalan untuk asuransi adalah rasa nyaman, bukan dalam rupiah. Kalaupun ada perusahaan asuransi yang menarik ROI, perlu dipahami bahwa asuransi bukanlah kendaraan investasi.

Dengan kata lain, jika Anda mengharapkan pengembalian investasi, kecuali jika terjadi kecelakaan, berinvestasi dalam asuransi harus menghasilkan pengembalian yang lebih rendah. Dana penyangga (buffer fund) yang tersedia untuk accident bukanlah imbalan investasi.

Bagaimana jika menabung pada aktiva tetap, misal properti? Untuk waktu yang lama, nilai properti biasanya meningkat pesat, namun bersifat illiquid dan biaya pajak dan administrasi cukup tinggi, berkisar 7-8\% dari nilai transaksi. Jadi jika Anda membeli properti senilai Rp 1.000, maka biaya keseluruhan berkisar Rp 1.080, dan jika Anda menjualnya berkisar Rp 1.137, maka nilai yang Anda terima Rp 1.080 atau kondisi impas. Perhatikan di sini, untuk kondisi impas diperlukan kenaikan harga berkisar 13,7\%.

\section{$\checkmark$ Dana dan Waktu}

Investasi manakah yang akan dipilih? Pertama, tergantung ketersediaan dana. Jika dana memadai, maka investor perlu membuat proporsi terlebih dahulu untuk dana tabungan (risk-free rate) dan aktiva berisiko. Karena rendahnya tingkat pengembalian (nilai riilnya tidak beranjak) maka hendaknya dipahami menabung bukanlah investasi.

Kedua, kadar risiko investasi harus disesuaikan dengan karakter investor. Pilihan investasi bukan persoalan benar salah, tetapi menyelaraskan antara risiko investasikarakter risiko investor. Investasi yang berisiko, sebaiknya dilakukan oleh risk lover-investor. 
Untuk investasi US\$1 dengan waktu 84 tahun, jika diinvestasikan pada tabungan (risk free rate), itu akan menghasilkan return berkisar 3.7\% dan nilai akhirnya menjadi US\$20,47. Sedangkan jika diinvestasikan pada saham, itu akan menghasilkan return 11,67\% dan nilai akhirnya menjadi US\$2.150 (Bodie, Kane, Marcus: 864). Untuk hal ini, saya teringat perkataan guru investasi bahwa, orang kaya tidaklah memegang uang, tetapi memegang kekayaan.

Ketiga, horison waktu yang dipilih. Pilihan investasi apakah akan diekskusi 1 tahun, 5 tahun, 10 tahun ke depan juga menentukan tipe investasi. Misalnya keperluan dana pendidikan anak 12 tahun ke depan, dapat dipenuhi dengan membeli saham (prospekif), sebagai pengganti dari menabung atau membeli asuransi pendidikan. Tentu saja harus dipahami, membeli saham memiliki konsekuensi (terburuk) emiten mengalami kebangkrutan. 


\section{BAB III \\ PENUTUP}

\section{A. Kesimpulan}

Teori Konsumsi adalah teori yang mempelajari bagaimana manusia / konsumen itu memuaskan kebutuhannya dengan pembelian / penggunaan barang dan jasa. Sedangkan pelaku konsumen adalah bagaimana ia memutuskan berapa jumlah barang dan jasa yang akan dibeli dalam berbagai situasi.

Fungsi konsumsi adalah suatu kurva yang menggambarkan sifat hubungan di antara tingkat konsumsi rumah tangga dalam perekonomian dengan pendapatan nasional (pendapatan disposebel) perekonomian tersebut. Fungsi konsumsi dapat dinyatakan dalam persamaan, Perkembangan ekonomi yang terjadi mengakibatkan bertambahnya variabel yang dapat mempengaruhi pengeluaran konsumsi selain pendapatan nasional, inflasi, suku bunga, dan jumlah uang beredar.

\section{B. Saran}

Dalam penyusunan makalah ini, penulis menyadari bahwa masih banyak kekurangan yang perlu ditambah dan diperbaiki. Untuk itu penulis mengharapkan inspirasi dari para pembaca dalam hal membantu menyempurkan makalah ini. Untuk terakhir kalinya penulis berharap agar dengan hadirnya makalah ini akan memberikan sebuah perubahan khususnya dunia pendidikan. 


\section{DAFTAR PUSTAKA}

Afif, M. (2017). Teori Permintaan dan Konsumsi Intertemporal antara Islam dan Konvensional. Jurnal Ekonomi Syariah, II(2), 229-242.

Asnawi, S. K. (2015, April 7). Investasi dan Tabungan. Diambil kembali dari investor.id: https://investor.id/archive/investasi-dan-tabungan

Habibullah, E. S. (2017). Etika Konsumsi Dalam Islam. Jurnal Ekonomi dan Bisnis Islam, I(1), 90-104.

Nursalih, A. (2014, September 3). Perilaku Konsumen. Diambil kembali dari Dosen Perbarnas: https://dosen.perbanas.id/perilaku-konsumen-fungsi-utilitas-dan-maslahah/?print=print

Qaradawi, Y. (1997). Norma dan Etika Ekonomi Islam. Jakarta: Gema Insani Press.

Samsul. (2019). Analisiss Pemanfaatan Harta dalam Konsumsi Masyarakat Ekonomi Konvensional dan Ekonomi Islam. Al-Azhar Journal of Islamic Economics, 1(2), 110-130.

Sukimo, S. (2011). Makroekonomi Teori Pengantar Edisi Ketiga. Jakarta: Raja Grafindo Persada. 